\title{
The Image of God in Ascetic Literature: Anthropomorphic Controversy According to Saint John Cassian's Conferences
}

\section{Cosmin Ionel MAFTEI*}

Abstract: According to Holy Bible, God cannot be seen by man, man can see The Face of God only from an eschatological perspective. Although, ,the glory of God" can be seen in certain conditions, more precisely in a mystical ecstatic state. In the second conference held by Father Isaac on the topic of the payer (Conference X), Saint John Cassian tells about the outburst of the anthropomorphic controversy. Here he rejects the anthropomorphic representation of God during prayer time, and so brings into discussing the topic of ,the face of God" referred to in Genesis 1, 26. From an allegorical point of view, he stresses the Christological perspective of the seeing God and warns about the anthropomorphic trap that leads to the loss of salvation. Following Holy Tradition and the most important Fathers, Saint John Cassian opposes the anthropomorphic ,heresy" and becomes the most important witness of this event.

Keywords: icon, prayer, origenist controversy, heresy, contemplation, Egyptian monasticism

* PhD candidate, Faculty of Orthodox Theology at "1 Decembrie 1918" University of Alba Iulia, Romania. 


\section{Introduction}

In the book of Exodus, God tells Moses: "you cannot see my face, for no one may see me and live"(33:20); in the same way, Saint Apostle Paul says about God that he "lives in unapproachable light" and "no one has seen or can see Him"(1Tim. 6:16). Although, Holy Bible states that God can be seen, but only in the future age, as Job tells: "And after my skin has been destroyed, yet in my flesh, I will see God; I myself will see him with my own eyes I, and not another" (19: 26-27). The righteous ones will "see His face" in the Jerusalem of Haven. Saint Apostle John says: "now we are children of God, and what we will be has not yet been made known. But we know that when Christ appears, we shall be like him, for we shall see him as he is" (1 John 3:2) and following the same idea, saint Apostle Paul states: "for now we see only a reflection as in a mirror; then we shall see face to face. Now I know in part; then I shall know fully, even as I am fully known."(1 Corinthians 13:12). Both Apostle John and Paul speak about "seeing God" as a consequence of knowing Him which means eternal life (John 17:3).

Although "the face of God" cannot be seen by someone in flesh, such contemplation having an eschatological nature, the glory of God can be seen after a certain period of preparation (Exodus 19:21; 33:18-23; John 1,14) as Lord Jesus Christ tells: "if you believe, you will see the glory of God"'(John11:40), or as Apostle Peter states referring to The Transfiguration of Christ "we were eyewitnesses of his majesty" (2 Peter 1:16). Interpreting the sequence/case of Martha and Mary, Saint John Cassian identifies, in an allegorical way, practice and theory (theoria) ${ }^{1}$. The last one

${ }^{1}$ Regarding this term, pr. Prof. Constantin COMAN, considers that translating it with ,contemplation” does not fit perfectly for its real meaning, preferring the term "vision" or "spiritual vision": Despre vederea lui 
means divine contemplation acquired by some saints who "feed on the beauty and knowledge of God alone"2. For John Cassian, theoria is the same with seeing God, with uniting with Him as much as is possible for man, but this can only be reached through ascetic labor (practice) $)^{3}$. The precise porpoise of ascetic life lived by monks is contemplation of God, vision of $\mathrm{God}^{4}$. This contemplation seems to be one of Glory as a result of mystical ecstasy as states Avva Silvan (Siluan): "I have been caught up to haven and saw the glory of God"5. The topic of God's contemplation or of the vision of God during prayer grew more and more in the ascetic literature of the Egyptian monasticism from the end of the IVth century, especially through the anthropomorphic controversy of which we will be talking further.

\section{Historical presentation/background}

In the second conference held with Father Isaac on the topic of prayer, Saint John Cassian (360-432) confesses even

Dumnezeu.Mărturii, (On Vision of God. Confessions), București, Editura Bizantină, s.a. p. 12.

${ }^{2}$ Saint JOHN CASSIAN, Conference I, VIII, 3, in Saint JOHN CASSIAN, Convorbiri duhovnicești (Conference), translated from Latin prof. David Popescu, București, Edit. Institutului Biblic și de Misiune al Bisericii Ortodoxe Române, 2004, p. 21.

3 Jean BREMOND, Părinții pustiei (Les Peres du Desert), second edition, introduction by Henri Bremond, introduction and notes translated from French by Marinela Bojin, București, Editura Nemira, 2010, p. 90.

4 Antoine GUILLAUMONT, Originile vieții monahale. Pentru o fenomenologie a monahismului(Aux origins du monachisme chretien. Pour une phenomenology du monachisme), translated by de Constantin Jinga, București, Editura Anastasia, 1998, p. 189.

5 Silvan 3, in ***Patericul sau Apoftegmele Părinților din Pustiu (Apophthecmata Patrum), alphabetical collection, translation, introduction, foreword by Cristian BĂDILIȚĂ, București, Editura Adevărul Holding, 2011, p. 338. 
from the beginning the fact that he was forced to intercalate some historical information too, "which may seem so to speak to cause a blemish on a fair body", especially when it is referred to "a doctrine so important" and represents "no small instruction on the image of Almighty God of which we read in Genesis". More exactly it is referred to a pastoral epistle of Bishop Theophilus of Alexandria from $399^{7}$ through which, along with announcing the celebration date for Easter, he "considered as well the foolish heresy of the Anthropomorphites at great length, and abundantly refuted it" ${ }^{\prime \prime}$. It seems that the mentioned epistle denied the human face of God (anthropomorphic) that was accepted by the majority of the monks of Egypt, creating so, in the Egyptian desert, a great disorder. The epistle has been read only by the community of father Paphnutius, to which belonged also Saint John Cassian.

In the Sketis community lived a monk named Serapion ${ }^{9}$, who has been living there for over 50 years, according to Saint John Cassian, and who could not accept the truth revealed by the epistle

6 Saint JOHN CASSIAN, Conference $X, I$, in Saint JOHN CASSIAN, Convorbiri duhovnicești (Conferences)...p. 249.

${ }^{7}$ Derwas J. CHITTY, Pustia - cetatea lui Dumnezeu. O introducere în studiul monahismului egiptean și palestinian din timpul Imperiului creștin (The Desert a City. An Introduction to the Study of Egyptian and Palestinian Monasticism under Christian Empire), translated from English by Gheorghe Fedorovici, București, Editura Sophia, 2010, p. 109.

${ }^{8}$ Saint JOHN CASSIAN, Conference $X, I I$, in Saint JOHN CASSIAN, Convorbiri duhovnicești (Conferences)...p. 249.

${ }^{9}$ Serapion is the name of an Egyptian god. This name was used by many Egyptian monks who converted to Christianity but who remained somehow attracted to their native religion - see: MASSEY Hamilton Shepherd, Jr., The Anthropomorphie Controversy in the Time of Theophilus of Alexandria, in Church History, vol. 7, No. 3 (Sep. 1938), published by: Cambridge University Press, pp. 270- 271. Even Cassian underlines the fact that Serapion's dismissal is connected to pagan superstition-Conference $X, V, 2$, in Saint JOHN CASSIAN, Convorbiri duhovnicești (Conferences)...p. 252. 
of Bishop Theophilus until all was cleared to him by a deacon from Cappadocia named Photin ${ }^{10}$ who showed that the anthropomorphic heresy is rejected by all Eastern Churches. Although "the old man was so bewildered in mind during his prayer because he felt that the Anthropomorphic image of the Godhead which he used to set before himself in prayer, was banished from his heart, that on a sudden he burst into a flood of bitter tears and continual sobs, and cast himself down on the ground and exclaimed with strong groanings: "Alas! wretched man that I am! they have taken away my God from me, and I have now none to lay hold of; and whom to worship and address I know not."'11

As a consequence to this letter many monks went to Alexandria demanding reckoning to bishop Theophilus who suddenly changed his attitude and rejected the origenist monks (intellectual monks) along with Origen's writings, event that made them (the origenists) leave the desert. Amongst others there were Saint John Cassian and Germanus ${ }^{12}$ who found shelter in

${ }^{10}$ His profile is very much alike to that of Evagrius Ponticus who according to Phaladius was enunciated ...... by Saint Basil the Great, enunciated deacon by Saint Gregory the Theologian. He also tells about Evagrius that he was good at rejecting heresies - PHALADIUS, Istoria Lausiacă (Lavsaiconul) (The Lausiac History), translation, introduction and notes by Preot Prof. Dr. Dumitru Stăniloae, București, Editura Institutului Biblic și de Misiune al Bisericii Ortodoxe Române, 2007, p. 87. Based on this research some scholars identity Photin as being Evagrius - see Gabriel BUNGE, Rugăciunea în Duh și Adevăr-filozofia și teologia capitolelor Despre rugăciune ale evvei Evagrie Ponticul și spiritualitatea Părinților pustiei (En Esprit et Verite. Etudes sur le traite Sur la Priere d'Evagre la Pontique), translated from Franch by Maria-Cornelia and diac. Ioan I. Ică jr, Sibiu, Deisis, 2015, pp. 98-100 și p. 95, note 111.

${ }^{11}$ Saint JOHN CASSIAN, Conference $X, I I I, 4-5$, in Saint JOHN CASSIAN, Convorbiri duhovnicești (Conferences)...p. 251.

12 Columba STEWART OSB, Cassian monahul. Invăţătura ascetico-mistică (Cassian the Monk), translated from English by diac. Ioan I. Ică jr. and Cristian Pop, Sibiu, Editura Deisis, 2000, p. 44. 
Constantinople at Saint John Chrysostom ${ }^{13}$. An important role in Theophilus changing (his) attitude had the anthropomorphist monk Aphou ${ }^{14}$, who after his discussion with the bishop ${ }^{15}$, clarified the literal interpretation over the verse from Genesis $1: 26^{16}$ and so leading to the acceptance of the anthropomorphic idea spread by the simple monks ${ }^{17}$. So being said, we can establish that Saint John Cassian is the most important witness and narrator of the anthropomorphic controversy, which due to Bishop Theophilus changing attitude became a hostile manifestation towards the intellectual monks, origenists, representing the forth part of the first origenist dispute ${ }^{18}$.

\section{Theological approach}

\subsection{The Image of God in Man (Genesis 1:26)}

The most important passage that was used to sustain both kind of ideas, both intellectual and anthropomorphist, is the one from Genesis 1:26-27: "Then God said, "Let us make

${ }^{13}$ Derwas J. CHITTY, Pustia - cetatea lui Dumnezeu...pp. 110-112.

${ }^{14}$ Elizabeth A. CLARK, New Perspectives on the ORIGENist Controversy: Human Embodiment and Ascetic Strategies, in Church History, vol. 59, No. 2 (Jun. 1990), published by: Cambridge University Press, pp. 148- 149.

15 Alexander GOLITZIN, The Vision of God and the Form of Glory: More Reflections on the Anthropomorphite Controversy of AD 399, in vol. John Behr, Andrew Louth, Dimitri Comonos, Abba: The Tradition of Orthodoxy in the West, New York, St. Vladimirs Seminary Press, 2003, pp. 286- 294.

${ }^{16}$ Anthropomorphist could sustain their arguments also based on the theology of Saint Irenaeus who sees the image of God in man also in mans body Pr. Dr. Ioan Goje, Sfântul Irineu- apărător al învățăturii creștine (Saint Irenaeus - Defender of the Christian Teachings), Cluj- Napoca, Editura Renașterea, 2002, pp. 179- 183.

${ }^{17}$ Columba STEWART OSB, Cassian monahul...p. 283, nota 15.

18 Nicolae- Dragoș KEREKES, ORIGENismul in secolele III- VIII (ORIGENism in IIIth to VIIIth century), Cluj- Napoca, Editura Renașterea, 2016, pp. 239- 242. 
mankind in our image, in our likeness, so that they may rule over the fish in the sea and the birds in the sky, over the livestock and all the wild animals, and over all the creatures that move along the ground." So God created mankind in his own image, in the image of God he created them; male and female he created them." This passage was interpreted literally by the anthropomorphist, so giving to God a human image, human characteristics, making God "human alike" or in an allegorical way by the origenists, stressing the spiritual alikeness of man with $\operatorname{God}^{19}$. This controversy became a taboo topic amongst Egyptian monks as we can observe from what abbot Sopatros says: "Abbot give me a command and I will guard it. He said: do not invite a woman into your cell, do not read apocrifes, and do not discus about the image of God in man, because this is not heresy but foolishness and argue between both parts. This cannot be understood by everyone" 20 .

This think could not be understood by Serapion either, although deacon Photin showed him that "the image and likeness of God was taken by all the leaders of the churches not according to the base sound of the letters, but spiritually, and supported this very fully and by many passages of Scripture, and showed that nothing of this sort could happen to that infinite and incomprehensible and invisible glory, so that it could be comprised in a human form and likeness, since its nature is incorporeal and uncompounded and simple, and what can neither be apprehended by the eyes nor conceived by the mind" 21 .

Origen, when he explains allegorically the passage from Genesis, shows that "in our image" should not be identified as

${ }^{19}$ Columba STEWART OSB, Cassian monahul...p. 149.

20 ***, Patericul sau Apoftegmele Părinților din Pustiu...p. 341.

${ }^{21}$ Saint JOHN CASSIAN, Conference $X, I I I, 3$, in Saint JOHN CASSIAN, Convorbiri duhovnicești (Conferences)...p. 250. 
corporal, as the anthropomorphist do, but rather with "soul", more exactly as mind and ration." "We do not understand, however, this man indeed whom Scripture says was made <according to the image of God> to be corporeal. For the form of the body does not contain the image of God, nor is the corporeal man said to be <made> but <formed>, as is written in the words which follow. For the text says: <And God formed man>, that is fashioned, from the slime of the earth. But it is our inner man, invisible, incorporeal, incorruptible, and immortal which is made <according to the image of God>."23

Origen indentifies the image in to the mind ${ }^{24}$, in intellect by which man rules over the world ${ }^{25}$. Saint John Chrysostom, an important member of the antiochian tradition, who explains Scriptures literally, shows that the image "does not mean likeliness of man with God by nature, but likeliness with Him by dominion; not regarded as an image of the form but as an image of dominion" 26 .

${ }^{22}$ Henri CROUZEL S.J., ORIGEN: personajul- exegetul- omul duhovnicescteologul (ORIGEN), second edition, translated from English by Cristian Pop, foreward by diac. Ioan I. Ică jr, Sibiu, Deisis, 2014, p. 184.

${ }^{23}$ Homily I, 13 to Genesis, in ORIGEN, Omilii, comentarii și adnotări la Geneză (Homilies on Genesis), bilingual edition, introductive study, translation and notes by Adrian Muraru, Iași, Polirom, 2006, p. 151.

${ }^{24}$ Even the Cappadocian Fathers identify the nous with God's place - see: Tomas SPIDLIK, Spiritualitea Răsăritului creştin, I- Manual sistematic(La spiritualite de l'Orient Chretiene - Manuel systematique), second edition, translated by diac. Ioan I. Ică jr., Sibiu, Editura Deisis, 2005, p. 383.

${ }^{25}$ Homily I, 12 to Genesis, in ORIGEN, Omilii, comentarii și adnotări la Geneză...p. 149.

${ }^{26}$ Homily IX, II, to Genesis, in Saint JOHN CHRISOSTOM, Omilii la Facere (Homilies on Genesis), vol. I, translated from Antient Greek by Dumitru Fecioru, București, Editura Institutului Biblic și de Misiune al Bisericii Ortodoxe Române, 2003, p. 93. 
Saint Basil the Great, a representative of the Cappadocian Fathers, shows that the image we should understand "as it is proper for God, not in a corporal way" ${ }^{27}$, detailing this aspect in his first homily On The Making of $\mathrm{Man}^{28}$. Saint Anthony the Great analyses in his letters ${ }^{29}$ the subject of "the image" from an origenist perspective, identifying it in the mind/intellect ${ }^{30}$. Following this, Abbot Evagrius Ponticus ${ }^{31}$, identifies the essence of "the image" in the way that the intellect accepts God and His knowledge $^{32}$. In front of so many testimonies that show the allegorical significance of "the image of God in man", given by Origen, Saint Basil the Great, Saint Anthony the Great, Evagrius Ponticul, and last but not least by Saint John Cassian ${ }^{33}$, the most significant antiorigenist and anthropomorphist supporter, saint Epiphanous of Salamina, is not categorical in his believe and

${ }^{27}$ Homily IX, VI to Hexaemeron, in Saint BASIL THE GREAT, Omilii la Hexaemeron (Homilies to Hexaemeron), translated by Pr. Dumitru Fecioru, București, Editura Sophia; Biserica Ortodoxă, 2004, p. 217.

${ }^{28}$ Homily, I, 4, in Saint BASIL THE GREAT, Omilii la facerea omului. Omilie despre Rai(Homilies on the Making of Man. Homily on Paradise), translated by Ierom. Lavrentie Carp, Iaşi, Editura Doxologia, 2010, pp. 27- 28.

${ }^{29}$ Published in Romanian in volume Gabriel BUNGE, Rugăciunea în Duh și Adevăr-filozofia și teologia capitolelor Despre rugăciune ale evvei Evagrie Ponticul și spiritualitatea Părinților pustiei..., pp. 551- 580.

${ }^{30}$ Gabriel BUNGE, Rugăciunea în Duh și Adevăr- filozofia și teologia capitolelor Despre rugăciune ale evvei Evagrie Ponticul şi spiritualitatea Părinților pustiei..., pp. 117-118.

31 The spiritual mentor of Saint John Cassian- Alexander GOLITZIN, Mistagogia: experiența lui Dumnezeu în Ortodoxie. Studii de teologie mistică (Mystagogy: Experiencing God in Orthodoxy. Studies of Mystical Theology), translated by diac. Ioan I. Ică jr, Sibiu, Editura Deisis, 1998, p. 196.

32 Gabriel BUNGE, Rugăciunea în Duh și Adevăr- filozofia și teologia capitolelor Despre rugăciune ale evvei Evagrie Ponticul și spiritualitatea Părinților pustiei..., p. 295.

${ }^{33}$ Saint JOHN CASSIAN, Conference $X, I I I, 3$, in Saint JOHN CASSIAN, Convorbiri duhovnicești (Conferences)...p. 250. 
does not inclines towards a literal or spiritual interpretation of "the image". In this regard he mentioned that there are many thinks that stop him from saying that "in our image" was made/created the body or the soul or the mind or the virtue, but nor he can say that the body or the soul are not "in our image" because it is something in man "in our image" but only God knows exactly what is that. ${ }^{34}$

\subsection{Vision of God}

The controversy between anthropomorphist and origenist, besides the differences in interpreting the passage from Genesis, that we have discussed above, was more about the way of understanding the content of seeing God. Saint John Cassian says through the words of father Isaac, making reference to monk Serapion, that: "we need not be surprised that a really simple man who had never received any instruction on the substance and nature of the Godhead could still be entangled and deceived by an error of simplicity and the habit of a longstanding mistake..., and (to speak more truly) continue in the original error which is brought about, not as you suppose by a new illusion of the demons, but by the ignorance of the ancient heathen world"35.

Cassian does not deny the possibility of contemplating/seeing God, from a christocentric perspective, but rather denies the simplicity, the palpable/sensory side of this kind of experience because "those cannot see Jesus coming in His Kingdom who are still kept back in a sort of state of Jewish weakness, and cannot say with the Apostle: And if we

34 Saint EPIPHANOUS OF SALAMINA, Ancoratus, 55, in Saint EPIPHANOUS OF SALAMINA, Ancoratus, bilingual edition, translated by Oana Coman, introductory studies by de Dragoș Mîrșanu, Iași, Editura Polirom, 2007, p. 181.

${ }^{35}$ Saint JOHN CASSIAN, Conference $X, V, 1,3$, in Saint JOHN CASSIAN, Convorbiri duhovnicești (Conferences)...pp. 251,252. 
have known Christ after the flesh, yet now we know Him so no more; 2 Corinthians 5:16 but only those can look with purest eyes on His Godhead, who rise with Him from low and earthly works and thoughts and go apart in the lofty mountain of solitude which is free from the disturbance of all earthly thoughts and troubles, and secure from the interference of all sins, and being exalted by pure faith and the heights of virtue reveals the glory of His Face and the image of His splendour to those who are able to look on Him with pure eyes of the soul." 36

Saint Epiphanous of Salamina in his work Ancoratus chapters 53 and 54 tells us about the characteristics of God's vision by the prophets, who confess that have seen Lord Sabaoth with their own eyes, condemning those who interpret Scriptures allegorically and who say that this visions cannot be true, thus considering the prophets liars. He does not accept the fact that the prophets would have seen with their mind, but not with their eyes, because they have indeed seen truly, but as much as it was possible to them. ${ }^{37}$ This does not mean that the essence of The Trinity can be perceived by senses, by the human eyes, as the messalians say, who believed in a mystical materialism. In change, for Evagrius, who taught a mystical intellectualism, the object of vision is the light of Trinity that shines in the pure intellect. In this regard, Evagrius rejects any visible epiphany. ${ }^{38}$

We notice here that if the different interpretation of the two sides over the verses from Genesis (1:26-27) represent the biblical-theological aspect of the anthropomorphic controversy,

36 Idem, Conference $X, V I, 2$, in Saint JOHN CASSIAN, Convorbiri duhovnicești...p. 253.

${ }^{37}$ EPIPHANOUS OF SALAMINA, Ancoratus... pp. 175-177.

${ }^{38}$ Vladimir LOSSKY, Vederea lui Dumnezeu (Vision of God), translated from English by prof. dr. Remus Rus, București, Editura Institutului Biblic şi de Misiune al Bisericii Ortodoxe Române, 1995, p. 94. 
the problem of God's corporality represents the philosophical ${ }^{39}$ aspect of it. The last of them makes Evagrius reject any anthropomorphic image of God as a sort of an iconoclasm directed towards mental images ${ }^{40}$. In this connection, the interdiction of the Ten Commandments to make any "graven image" of God, to create an image of God, is strengthen, according to Evagrius by the fact that Christ forbid "the sin in thought", thus being forbidden the mental images of God in an anthropomorphic way ${ }^{41}$. Even Saint John Cassian opposes to the idea of replacing a Person with an image, someone by something, therefore he stresses the vision of Christ in glory. By the end of his life Cassian states that he has seen a light, a wonderful clearness, a brightness in front of which the human weakness cannot stand, and human eyes cannot bear. He concludes in the end that he has seen the glory of God shining as an extraordinary light. ${ }^{42}$

Cassian's experience resembles to the one confessed by Abbot Silvan (Siluan). He said that he was caught to haven and he saw the glory of God ${ }^{43}$, or to the one reported by Apostle Paul in the second Epistle to the Corinthians where he states that he was caught to the third haven to "what no eye has seen, what no ear has heard, and what no human mind has conceived" the things God has prepared for those who love him - these are the things

39 Gabriel BUNGE, Rugăciunea în Duh și Adevăr- filozofia și teologia capitolelor Despre rugăciune ale avvei Evagrie Ponticul și spiritualitatea Părinților pustiei..., p. 113.

${ }^{40}$ Elizabeth A. CLARK, New Perspectives on the ORIGENist Controversy: Human Embodiment and Ascetic Strategies..., p. 154.

${ }^{41}$ Gabriel BUNGE, Rugăciunea în Duh și Adevăr- filozofia și teologia capitolelor Despre rugăciune ale evvei Evagrie Ponticul și spiritualitatea Părinților pustiei, ..., p. 337.

${ }^{42}$ Columba STEWART OSB, Cassian monahul...p. 160.

${ }^{43}$ Silvan 3, in Patericul sau Apoftegmele Părinților din Pustiu ..., p. 338. 
God has revealed to us by his Spirit. The Spirit searches all things, even the deep things of God. (1 Corinthians 2:9-10)".

Even for Evagrius, who rejects any vision intermediated by senses, vision represents seeing a pure light with no precise form, free not only from any kind of thought belonging to our tangible world but also from any intelligible manifestation, free from any representation, even of God Itself ${ }^{44}$.

Vision of God as light is an important aspect of the mysticism presented by Saint Macarius the Great ${ }^{45}$ through his homilies. In this regard he states that the light that shines in our heart finds a deeper, profound light. If the man sinks into this second light, he is no longer in control of his actions, of his own being, he becomes as a stranger for this world ${ }^{46}$. For Macarius, vision of God is possible due to some spiritual senses ${ }^{47}$. He states this not being aware of the messalian materialistic perspective of spirituality ${ }^{48}$. Saint Macarius reports, related to the topic of the vision of God, that the Kingdome of light and the heavenly image of Christ lights up our soul in a mystical way and rules in the soul of the saints. So being hidden from the eyes of man, Christ can be

${ }^{44}$ Antoine GUILLAUMONT, Originile vieții monahale..., p. 199.

${ }^{45}$ Teacher of Evagrius Ponticus.

${ }^{46}$ Saint MACARIUS THE GREAT, Homily VIII, 3, in Saint MACARIUS THE GREAT, Omilii duhovnicești (Spiritual Homilies), translated from Greek by Pr. prof. dr. Constantin Cornițescu, București, Editura Institutului Biblic și de Misiune al Bisericii Ortodoxe Române, 2010, p. 68.

${ }^{47}$ The teaching about spiritual senses is originated from ORIGEN, influencing a lot the future mysticism - see Andrew LOUTH, Originile tradiției mistice creștine. De la Platon la Dionisie Areopagitul (The Origins of the Christian Mystical Tradition from Plato to Denys), translated by Elisabeta Voichița Sita, foreword by diac. Ioan I. Ică jr, Sibiu, Editura Deisis, 2002, p. 102.

48 Cătălin PĂLIMARU, Teologia experienței în Corpusul macarian (The Theology of Experience in Macarianus Corpus), foreword by Arhid. Prof. dr. Ioan I. Ică jr, Cluj-Napoca, Editura Renașterea, 2014, p. 275. 
truly seen with the eyes of the soul ${ }^{49}$. The notion of spiritual senses is presented in the work of John Cassian as well, thus he uses expressions like "eyes of mind" 50 , "eyes of the soul" 51 , "eyes of the spirit"

Is important to emphasize that the vision of the light of God in the indwelling mind (nous) represents for Evagrius the higher point of the spiritual life. This is why there is no ecstasy, no apophatic knowledge. This idea we find also at Origen. He explains that because the nous finds his true nature by uniting with God there can be no ecstasy. God is not unknowable, thus being introduced the idea of a mysticism of light ${ }^{54}$. In this regard, according to Evagrius, the soul finds his original/primordial state of nous in prayer, thus the nous, that is the image of God, becomes pure light, and from this high intellectual point reflects the light of the Holy Trinity, but it is not ecstatic, but katastatic ${ }^{55}$.

Instead, for Saint John Cassian ecstatic experiences ${ }^{56}$ are representative for his spiritual teaching. Thus we can observe the comparison made by Cassian between the evagrian and the macarian, Syrian spirituality, comparison that anticipates the ones made by Diadochus of Photice, Saint Maximus the Confessor and

${ }^{49}$ Saint Macarius the Great, Homily II, 5, in Saint MACARIUS THE GREAT, Omilii duhovnicești..., p. 22.

${ }^{50}$ Saint JOHN CASSIAN, Conference I, XIII, 2, in Saint JOHN CASSIAN, Convorbiri duhovnicești (Conferences)...p. 22.

${ }^{51}$ Idem, Conference V, XV, 4, in Saint JOHN CASSIAN, Convorbiri duhovnicești...p. 126.

${ }^{52}$ Idem, Conference V, XVI, 6, in Saint JOHN CASSIAN, Convorbiri duhovnicești......p. 128.

${ }^{53}$ Idem, Conference VII, XXI, 4, in Saint JOHN CASSIAN, Convorbiri duhovnicești......p. 176.

${ }^{54}$ Andrew Louth, Originile tradiției mistice creștine....p. 109.

55 Tomas SPIDLIK, Spiritualitea Răsăritului creştin, I- Manual sistematic..., p. 394.

${ }^{56}$ Saint JOHN CASSIAN, Conference IX, XXVII; X, XI, 6. 
Saint Symeon The New Theologian. According to Columba Stewart this extraordinary accomplishment of John Cassian remained practically unknown to the modern scholars ${ }^{57}$. Although the Russian theologian Vladimir Lossky in his work "Vision of God", referring to the vision of God in ascetic literature, analyses the mysticism of Evagrius, Macarius the Great and Diadochus of Photice, showing that the last makes a comparison between the mysticism of the intellect (evagrian) and the mysticism of light, of experiences of grace specific to the macarian homilies. Due to this comparison he made, Diadochus is considered by Lossky to be the forefather of the Byzantine isihasm ${ }^{58}$, but this work has been conducted by Cassian decades earlier.

Vision of God is conditioned by the pureness of heard (Mathew 5:8). This idea has been detailed by Cassian thus showing that our goal is eternal life, The Kingdome of God, and a pure heart represents the means to reach it ${ }^{59}$. The mind has also an important role in this process because "this, I say, is the end of all perfection, that the mind purged from all carnal desires may daily be lifted towards spiritual things, until the whole life and all the thoughts of the heart become one continuous prayer." ${ }^{.60}$ The richest prayer according to Cassian is the prayer of fire known and practiced by few, during which the mind is lighted by the heavenly bliss. ${ }^{61}$

${ }^{57}$ Columba STEWART, Casian monahul.....p. 146.

${ }^{58}$ Vladimir LOSSKY, Vederea lui Dumnezeu......p. 101.

${ }^{59}$ Saint JOHN CASSIAN, Conference I, IV,3; I, V, 2, in Saint JOHN CASSIAN, Convorbiri duhovnicești (Conferences)...pp. 16-17.

${ }^{60}$ Idem, Conference X, VII, 3, in Saint JOHN CASSIAN, Convorbiri duhovnicești (Conferences)...pp. 254- 255.

${ }^{61}$ Idem, Conference IX, XXVI in Saint JOHN CASSIAN, Convorbiri duhovnicești (Conferences)...p. 237. 
2.3. The foolish heresy of the Anthropomorphites ${ }^{62}$

Not accidentally Saint John Cassian approaches the anthropomorphic controversy in his conference on prayer held with father Isaac. This is intended precisely for the fact that this controversy has a profound spiritual aspect. More to say, he may also follow his master, Evagrius Ponticus ${ }^{63}$, who as well wrote "On Prayer" as an answer to this spiritual crises within the Egyptian monasticism, according to Gabriel Bunge. Thus Evagrius cannot be considered the initiator of this controversy as Antoine Guillaumont ${ }^{64}$ thinks. Although, as we could have seen above, Cassian differentiates himself from Evagrius from what prayer is concerned as least in two aspects. First Cassian mysticism is Christological and abbot Evagrius speaks of trinitary mysticism ${ }^{65}$ and second, for Cassian ecstasy is defining in order to reach a full connection with God, while for Evagrius ecstasy is almost non-existent.

In its approach, Cassian opposes to the anthropomorphist prayer practiced by Serapion: "Alas! wretched man that I am! they have taken away my God from me, and I have now none to

62 Idem, Conference X, II, 2, in Saint JOHN CASSIAN, Convorbiri duhovnicești (Conferences).......p. 249.

${ }^{63}$ Cristian BĂDILIȚĂ, „Viața şi scrierile lui Evagrie Ponticul- un continuu exercițiu spiritual” ( ,Life and Writings of Evagrius Ponticus - A Continuous Spiritual Exercise"), in Evagrius Ponticus, Tratatul practic. Gnosticul (Praktikos), second edition, introduction, translation and comments by Cristian Bădiliță, Iași, Edit. Polirom, 2003, p. 22 (see footnote no. 2).

${ }^{64}$ For further study see Gabriel BUNGE, Rugăciunea în Duh și Adevărfilozofia și teologia capitolelor Despre rugăciune ale avvei Evagrie Ponticul și spiritualitatea Părinților pustiei,..., pp. 63-64, 215-216.

${ }^{65}$ For more details see Gabriel BUNGE, Rugăciunea în Duh și Adevărfilozofia și teologia capitolelor Despre rugăciune ale avvei Evagrie Ponticul și spiritualitatea Părinților pustiei,..., pp. 265- 284. 
lay hold of; and whom to worship and address I know not." ${ }^{\circ 6}$, the spiritual state of the true prayer practiced by Antony the Great who declares to be disturbed by the sunrise that interrupts his prayer: "Why do you hinder me, $\mathrm{O}$ sun, who art arising for this very purpose; to withdraw me from the brightness of this true light?". The idea is continued by the same Abbot Antony, clarifying the concept of true prayer "That is not, said he, a perfect prayer, wherein a monk understands himself and the words which he prays." ${ }^{\circ}$. The argument stressed by Cassian when he confutes the anthropomorphist prayer is the role of imagination during prayer ${ }^{68}$, imagination which, according to Evagrius, is the fruit of the passions present in the heart ${ }^{69}$. Thereby, we can say that in this situation there is a great risk of demonic deception ${ }^{70}$. An example is that of monk Heron ${ }^{71}$ who was deceived by demons because he could not follow Saint

${ }^{66}$ Saint JOHN CASSIAN, Conference $X, I I I, 4-5$, in Saint JOHN CASSIAN, Convorbiri duhovnicești (Conferences)...p. 251.

67 Idem, Conference IX, XXXI, in Saint JOHN CASSIAN, Convorbiri duhovnicești (Conferences)......p. 241.

${ }^{68}$ Columba STEWART, Casian monahul.....p. 147; Gabriel BUNGE, Rugăciunea in Duh şi Adevăr-filozofia și teologia capitolelor Despre rugăciune ale avvei Evagrie Ponticul și spiritualitatea Părinților pustiei,..., p. 96.

${ }^{69}$ Despre rugăciune 72 (On Prayer 72), in ***Filocalia I, translated from Greek by Pr. Prof. Dr. Dumitru Stăniloae, București, Editura Institutului Biblic și de Misiune al Bisericii Ortodoxe Române, 2008, pp. 107- 108.

${ }^{70}$ Do not wish to see any kind of image in time of prayer. Do not wish to see angels, or Christ or the Face of Almighty God, for not to be deceived by demons. „Nu căuta nicidecum să primești vreun chip sau vreo înfățișare în vremea rugăciunii, din dorul de a vedea faţa Tatălui cel din ceruri. Nu dori să vezi Îngeri, sau Puteri, sau pe Hristos în chip sensibil, ca să nu-ți ieși cu totul din minte luînd lupul drept păstor și închinîndu-tebdracilor vrăjmași”- Monk Evagrius, Despre rugăciune (On Prayer), 114, 115- in Filocalia I..., p. 114.

${ }^{71}$ Saint JOHN CASSIAN, Conference II, $V$, in Saint JOHN CASSIAN, Convorbiri duhovnicești (Conferences).......pp. 44- 45. 
Antony's advice for a right judgment ${ }^{72}$. Monks like Heron and Serapion stand as examples for what Saint Antony says: "Some have afflicted their bodies by asceticism, but they lack discernment, and so they are far from God." ${ }^{73}$

John Cassian shows his concern for those who practice an anthropomorphist prayer that will distance them from God. So he speaks of the anthropomorphic heresy as being a novelty unfounded either on the older teachings nor on tradition but of great danger that can lead to eternal death ${ }^{74}$. The word "heresy" used by Casian along with other fathers of the desert has a deep spiritual value. In this regard I emphasize the story of Abbot Agathon who has been accepting any denigration brought to him but when he is asked if he was a heretic he says no for an answer. When he is asked to clarify his answer he states that all accusations that he received before he accepted as being true because that was useful for his soul, but being an heretic is much more, it means to create a rupture between man and God. ${ }^{75}$

This being said, Cassian is entitled to use the word heresy when speaking about anthropomorphism. Thus he underlines a dismissal from the true faith and from the true prayer. Columba Stewart develops this idea when he says that anthropomorphic prayer puts the arian controversy into a spiritual dimension, more exactly if the human mind sees God in a human shape, God is reduced at a human level. If Christ is contemplated only in His

${ }^{72}$ Idem, Conference II, II, in Saint JOHN CASSIAN, Convorbiri duhovnicești (Conferences).......pp. 40- 41.

73 Antony the Great, 8, in ***Patericul sau Apoftegmele Părinților din Pustiu,..., p. 44.

${ }^{74}$ Saint John Chrysostom, Convorbirea X, II-IV, în volumul Sf. Ioan Casian, Convorbiri duhovnicești...pp. 249- 251.

75 Agathon, 5, în volumul ***Patericul sau Apoftegmele Părinților din Pustiu,..., p. 70. 
earthly humanity and in this situation He cannot be encountered in his heavenly glorifying sate. ${ }^{76}$

Saint John Cassian is the most important witness of the anthropomorphist controversy burst out in the Egyptian desert at the end of the IVth century. At the same time he is a redundant combatant of this heresy offering a valid and deeply theological answer through which he demonstrates his allegiance to the tradition of the Holy Fathers, both theologians of Nicene and monks from Egypt. He is a dignified follower of the Cappadocian Fathers but also of his mentors Evagrius Ponticus and Saint John Chrysostom.

\section{References}

1.BĂDILIȚĂ Cristian, „Viața și scrierile lui Evagrie Ponticul- un continuu exercițiu spiritual” ( „Life and Writings of Evagrius Ponticus - A Continuous Spiritual Exercise"), in Evagrius Ponticus, Tratatul practic. Gnosticul (Praktikos), second edition, introduction, translation and comments by Cristian BĂDILIȚĂ, Iași, Edit. Polirom, 2003.

2.*** Biblia sau Sfânta Scriptură (The Bible), ediția Sfântului Sinod, București, Editura Institutului Biblic și de Misiune al Bisericii Ortodoxe Române, 2001.

3.Saint BASIL THE GREAT, Omilii la facerea omului. Omilie despre Rai(Homilies on the Making of Man. Homily on Paradise), translated by Ierom. Lavrentie Carp, Iași, Editura Doxologia, 2010.

4.Saint BASIL THE GREAT, Omilii la Hexaemeron (Homilies to Hexaemeron), translated by Pr. Dumitru Fecioru, Bucureşti, Editura Sophia; Biserica Ortodoxă, 2004.

5.BREMOND Jean, Părinții pustiei (Les Peres du Desert), second edition, introduction by Henri Bremond, introduction and notes

${ }^{76}$ Columba STEWART, Casian monahul.....p. 150. 
translated from French by Marinela Bojin, București, Editura Nemira, 2010.

6.BUNGE Gabriel, Rugăciunea în Duh şi Adevăr- filozofia și teologia capitolelor Despre rugăciune ale evvei Evagrie Ponticul și spiritualitatea Părinţilor pustiei (En Esprit et Verite. Etudes sur le traite Sur la Priere d'Evagre la Pontique), translated from Franch by Maria-Cornelia and diac. Ioan I. Ică jr, Sibiu, Deisis, 2015.

7.CHITTY Derwas J., Pustia - cetatea lui Dumnezeu. O introducere în studiul monahismului egiptean și palestinian din timpul Imperiului creștin (The Desert a City. An Introduction to the Study of Egyptian and Palestinian Monasticism under Christian Empire), translated from English by Gheorghe Fedorovici, București, Editura Sophia, 2010.

8.CLARK Elizabeth A., New Perspectives on the ORIGENist Controversy: Human Embodiment and Ascetic Strategies, in Church History, vol. 59, No. 2 (Jun. 1990).

9.COMAN Constantin, Despre vederea lui Dumnezeu.Mărturii, (On Vision of God. Confessions), București, Editura Bizantină, s.a.

10.CROUZEL Henri S.J., ORIGEN: personajul- exegetul- omul duhovnicesc- teologul (ORIGEN), second edition, translated from English by Cristian Pop, foreward by diac. Ioan I. Ică jr, Sibiu, Deisis, 2014.

11.Saint EPIPHANOUS OF SALAMINA, Ancoratus, bilingual edition, translated by Oana Coman, introductory studies by de Dragoș Mîrșanu, Iași, Editura Polirom, 2007.

12. ***Filocalia I, translated from Greek by Pr. Prof. Dr. Dumitru Stăniloae, București, Editura Institutului Biblic și de Misiune al Bisericii Ortodoxe Române, 2008.

13.GOLITZIN Alexander, Mistagogia: experiența lui Dumnezeu în Ortodoxie. Studii de teologie mistică (Mystagogy: Experiencing God in Orthodoxy. Studies of Mystical Theology), translated by diac. Ioan I. Ică jr, Sibiu, Editura Deisis, 1998.

14.GOLITZIN Alexander, The Vision of God and the Form of Glory: More Reflections on the Anthropomorphite Controversy of $A D$ 399, in vol. John Behr, Andrew Louth, Dimitri 
The Image of God in Ascetic Literature: Anthropomorphic Controversy According to Saint John Cassian's Conferences

Comonos, Abba: The Tradition of Orthodoxy in the West, New York, St. Vladimirs Seminary Press, 2003.

15.GUILLAUMONT Antoine, Originile vieții monahale. Pentru o fenomenologie a monahismului(Aux origins du monachisme chretien. Pour une phenomenology du monachisme), translated by de Constantin Jinga, București, Editura Anastasia, 1998.

16.Saint JOHN CASSIAN, Convorbiri duhovnicești (Conference), translated from Latin prof. David Popescu, București, Edit. Institutului Biblic şi de Misiune al Bisericii Ortodoxe Române, 2004.

17.Saint JOHN CHRISOSTOM, Omilii la Facere (Homilies on Genesis), vol. I, translated from Antient Greek by Dumitru Fecioru, București, Editura Institutului Biblic și de Misiune al Bisericii Ortodoxe Române, 2003.

18.KEREKES Nicolae- Dragoș, ORIGENismul în secolele III-VIII (ORIGENism in IIIth to VIIIth century), Cluj- Napoca, Editura Renașterea, 2016.

19.LOSSKY Vladimir, Vederea lui Dumnezeu (Vision of God), translated from English by prof. dr. Remus Rus, Bucureşti, Editura Institutului Biblic și de Misiune al Bisericii Ortodoxe Române, 1995.

20.LOUTH Andrew, Originile tradiției mistice creștine. De la Platon la Dionisie Areopagitul (The Origins of the Christian Mystical Tradition from Plato to Denys), translated by Elisabeta Voichița Sita, foreword by diac. Ioan I. Ică jr, Sibiu, Editura Deisis, 2002.

21.Saint MACARIUS THE GREAT, Omilii duhovnicești (Spiritual Homilies), translated from Greek by Pr. prof. dr. Constantin Cornițescu, București, Editura Institutului Biblic și de Misiune al Bisericii Ortodoxe Române, 2010.

22.MASSEY Hamilton Shepherd, Jr., The Anthropomorphie Controversy in the Time of Theophilus of Alexandria, in Church History, vol. 7, No. 3. (Sep. 1938).

23.ORIGEN, Omilii, comentarii şi adnotări la Geneză (Homilies on Genesis), bilingual edition, introductive study, translation and notes by Adrian Muraru, Iași, Polirom, 2006. 
24.PĂLIMARU Cătălin, Teologia experienței în Corpusul macarian (The Theology of Experience in Macarianus Corpus), foreword by Arhid. Prof. dr. Ioan I. Ică jr, Cluj-Napoca, Editura Renașterea, 2014.

25.***Patericul sau Apoftegmele Părinţilor din Pustiu (Apophthecmata Patrum), alphabetical collection, translation, introduction, foreword by Cristian BĂDILIȚĂ, București, Editura Adevărul Holding, 2011.

26.PHALADIUS, Istoria Lausiacă (Lavsaiconul) (The Lausiac History), translation, introduction and notes by Preot Prof. Dr. Dumitru Stăniloae, București, Editura Institutului Biblic și de Misiune al Bisericii Ortodoxe Române, 2007.

27.SPIDLIK Tomas, Spiritualitea Răsăritului creştin, I- Manual sistematic(La spiritualite de l'Orient Chretiene - Manuel systematique), second edition, translated by diac. Ioan I. Ică jr., Sibiu, Editura Deisis, 2005.

28.STEWART Columba OSB, Cassian monahul. Invățătura ascetico-mistică (Cassian the Monk), translated from English by diac. Ioan I. Ică jr. and Cristian Pop, Sibiu, Editura Deisis, 2000 . 